\title{
Correction to: Differences in myoelectric activity of the lumbar muscles between recurrent and chronic low back pain: a cross-sectional study
}

Mercè Balasch-Bernat ${ }^{1,2}$, Tine Willems ${ }^{3,4^{*}}$, Lieven Danneels ${ }^{3}$, Mira Meeus ${ }^{3,5,6}$ and Dorien Goubert ${ }^{3,5}$

Correction to: BMC Musculoskelet Disord 22, 756 (2021)

\section{https://doi.org/10.1186/s12891-021-04623-9}

Following the publication of the original article [1] the authors noticed that the reference for the manuscript is incorrect; the authors' first and last names were swapped.

The reference should be:

Balasch-Bernat, M., Willems, T., Danneels, L., Meeus M. and Goubert, D. Differences in myoelectric activity of the lumbar muscles between recurrent and chronic low back pain: a cross-sectional study. BMC Musculoskelet Disord 22, 756 (2021). https://doi.org/10.1186/ s12891-021-04623-9.

The original article [1] has been updated.

\begin{abstract}
Author details
${ }^{1}$ Department of Physiotherapy, University of Valencia, Valencia, Spain. ${ }^{2}$ Physiotherapy in Motion, MultiSpeciality Research Group (PTinMOTION), University of Valencia, Valencia, Spain. ${ }^{3}$ Department of Rehabilitation Sciences, Faculty of Medicine and Health Sciences, Ghent University, Ghent, Belgium. ${ }^{4}$ Department of Rehabilitation Sciences, Campus Heymans (UZ) 3 B3, Corneel Heymanslaan 10, 9000 Ghent, Belgium. ${ }^{5}$ Pain in Motion Research Group, Valencia, Spain. ${ }^{6}$ Department of Rehabilitation Sciences and Physiotherapy, Faculty of Medicine and Health Sciences, University of Antwerp, Antwerp, Belgium.
\end{abstract}

The original article can be found online at https://doi.org/10.1186/s12891021-04623-9.

*Correspondence: Tine.Willems@ugent.be

${ }^{4}$ Department of Rehabilitation Sciences, Campus Heymans (UZ) 3 B3,

Corneel Heymanslaan 10, 9000 Ghent, Belgium

Full list of author information is available at the end of the article
Published online: 22 October 2021

\section{Reference}

1. Balasch-Bernat M, Willems T, Danneels L, et al. Differences in myoelectric activity of the lumbar muscles between recurrent and chronic low back pain: a cross-sectional study. BMC Musculoskelet Disord. 2021;22:756. https://doi.org/10.1186/s12891-021-04623-9.

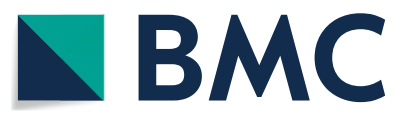

(c) The Author(s) 2021. Open Access This article is licensed under a Creative Commons Attribution 4.0 International License, which permits use, sharing, adaptation, distribution and reproduction in any medium or format, as long as you give appropriate credit to the original author(s) and the source, provide a link to the Creative Commons licence, and indicate if changes were made. The images or other third party material in this article are included in the article's Creative Commons licence, unless indicated otherwise in a credit line to the material. If material is not included in the article's Creative Commons licence and your intended use is not permitted by statutory regulation or exceeds the permitted use, you will need to obtain permission directly from the copyright holder. To view a copy of this licence, visit http://creativecommons.org/licenses/by/4.0/. The Creative Commons Public Domain Dedication waiver (http://creativeco mmons.org/publicdomain/zero/1.0/) applies to the data made available in this article, unless otherwise stated in a credit line to the data. 